\title{
Successional stage effect on the availability of tree cavities for cavity-nesting birds in an Atlantic Forest park from the state of São Paulo, Brazil
}

\author{
Michele Viana Katayama ${ }^{1}$, Paulo Victor Queijo Zima ${ }^{1}$, Daniel Fernandes Perrella ${ }^{I}$ \& \\ Mercival Roberto Francisco ${ }^{2 *}$ \\ ${ }^{1}$ Universidade Federal de São Carlos, Programa de Pós-Graduação em Ecologia e Recursos Naturais, \\ Rod. Washington Luiz, Km 235, 13565-905, São Carlos, SP, Brazil. \\ ${ }^{2}$ Universidade Federal de São Carlos, Depto. de Ciências Ambientais, campus de Sorocaba, Rod. João Leme dos \\ Santos, km 110, 18052-780, Sorocaba, SP, Brazil. \\ *Corresponding author: Mercival Roberto Francisco,e-mail:mercival@ufscar.br
}

KATAYAMA, M. V., ZIMA, P. V. Q., PERRELlA, D. F., FRANCISCO, M. R. Successional stage effect on the availability of tree cavities for cavity-nesting birds in an Atlantic Forest park from the state of São Paulo, Brazil. Biota Neotropica. 17(4): e20170391. http://dx.doi.org/10.1590/1676-0611-BN-2017-0391

\begin{abstract}
The availability of suitable cavities and substrate for hole construction can limit the populations of birds that rely on tree hollows to reproduce. Several studies have focused on the effects of types of habitats, and types of human disturbances on cavities abundance, but the effect of successional stages in the Atlantic Forest has been poorly addressed. In this study we aimed to compare the availability and biometric characteristics of tree cavities between primary and mid-successional stage sites in an Atlantic Forest area from southeastern Brazil. Based on nest characteristics described in the literature, we inferred if hollows present in secondary sites could harbor the large secondary-nester Atlantic Forest birds, with special attention to toucans and hawks. From September 2016 to April 2017, 96 cavities were sampled, 67 in the primary, and 29 in the secondary plots. Our data revealed that the communities of cavity-nester birds in mid-successional stage areas may be more affected by the reduced cavity availability than by cavities quality, as the number of cavities in these sites was less than half than that found in mature forests. We also provide evidences that the largest cavity nesters, such as the biggest hawks, might have limited nesting possibilities in mid-successional stage areas especially due to small cavity entrances, which may have important reflects in conservation strategies.
\end{abstract}

Keywords: Bird conservation, nesting ecology, cavity-nesters

\section{Efeito do estágio sucessional na disponibilidade de cavidades para aves que nidificam em ocos de árvores em um parque da Mata Atlântica do Estado de São Paulo, Brasil}

Resumo: A disponibilidade de cavidades adequadas e o substrato para a escavação de ocos podem limitar as populações de aves que dependem das cavidades de árvores para se reproduzir. Vários estudos se concentraram nos efeitos dos tipos de habitats e em tipos de distúrbios antrópicos sobre a disponibilidade de cavidades, mas o efeito da sucessão ecológica na Mata Atlântica é muito pouco investigado. Neste estudo, buscamos comparar a disponibilidade e algumas características biométricas das cavidades de árvores entre áreas em estágio primário e secundário-médio na Mata Atlântica do sudeste do Brasil. Baseado nas características dos ninhos das espécies que ocorrem na área de estudo, também deduzimos se as cavidades que estão presentes em áreas secundárias poderiam abrigar as maiores aves que nidificam em cavidades, mas que são incapazes de escavá-las, com atenção especial aos tucanos e falcões. De setembro de 2016 a abril de 2017, 96 cavidades foram amostradas, 67 em áreas primárias e 29 em parcelas em locais de floresta secundária. Nossos dados revelaram que a comunidade de aves dependentes de ocos para nidificação em áreas em estágio médio de sucessão podem ser mais afetadas pela baixa disponibilidade de cavidades do que pela qualidade das cavidades, já que o número de cavidades nesses locais foi menos da metade do que o encontrado em florestas maduras. Também evidenciou-se que os nidificadores de cavidades de maior porte, como os grandes falcões, podem ter possibilidades de nidificação limitadas nas áreas de estágio médio de sucessão, especialmente devido ao tamanho reduzido das entradas de cavidades, o que pode ter importantes reflexos em estratégias de conservação.

Palavras-chave: conservação de avifauna, ecologia reprodutiva, nidificadores de cavidades 


\section{Introduction}

Bird species that use tree cavities for nesting can be classified as i) excavators, or primary cavity nesters, and ii) non-excavators, or secondary cavity nesters. Excavators build their own cavities usually in dead trees or branches and are represented mainly by the woodpeckers, whereas the non-excavators depend on pre-existing cavities such as natural holes present in live or decaying trees, or those created by the excavators (e.g. toucans, woodcreepers, and parrots) (Martin \& Eadie 1999, Jackson $\&$ Jackson 2004). As predation is often the main cause of nest failures (Li \& Martin 1991, Wesolowski 2002, Miller 2002, Cockle \& Bodrati 2009, Wiebe \& Swift 2001), suitable cavities for birds reproduction are expected to present: a small entrance capable to avoid the passage of predators that are bigger than the nesting bird; depth enough to avoid predators to reach nest contents, and hard walls to impede nest access by predators through wood destruction (Wesolowski 2002). Therefore, the availability of adequate natural cavities and of substrate for holes construction can limit the populations of birds that rely on tree hollows to reproduce (Lõhmus \& Remm 2004, Cockle et al. 2008, 2010).

Many types of anthropogenic activities are known to impact the density and quality of tree cavities, and the resulting decline of cavity-nesting species has been reported for bird communities all over the world (for a review, see Cornelius et al. 2008). For instance, the selective logging of the largest trees in areas of mature forest has often been accompanied by the depletion of the largest birds that depend on big cavities to reproduce (Bai et al. 2003, Politi et al. 2010, Cockle et al. 2011a). A similar effect occurs in secondary forests, where the density of large cavities tends to decrease due to the smaller diameter of the trees (Willis \& Oniki 2001, Cornelius et al. 2008, Cockle et al. 2011a). Further, timber management practices based on the exploitation of decaying trees have caused disastrous declines in cavity-nesting birds in Europe and North America (Dobkin et al. 1995, Aitken et al. 2002, Franco et al. 2005). These are evidences that forest type, successional stage, and degree of human disturbance are key elements for cavity nests availability and for the persistence of cavity-nesting birds (Cornelius et al. 2008).

The Atlantic Forest is one of the most threatened biomes and one of the five main hotspots on earth (Myers et al. 2000). Besides, it is the second richest area in bird species in the world (Remsen et al. 2015, Piacentini et al. 2015). The biome's original area covered more than one million square kilometers (SOS Mata Atlântica and INPE 2016), but only about $11.7 \%$ is left, and $42 \%$ of the remaining area consists of fragments smaller than 250 ha that suffer varying degrees of disturbance and threats (Ribeiro et al. 2009). In this scenario, cavity nesting species may be particularly vulnerable, and understanding the factors that influence the persistence of these species is urgently needed (Cockle et al. 2010, 2015). Cockle et al. (2010) demonstrated that in the subtropical Atlantic Forest of Argentina there were nine times fewer cavities in logged than in areas of unmanaged primary forest, and Cockle et al. (2015) showed that in the same region, when trees with desirable characteristics were maintained, several species of cavity nesting birds could succeed in reproduction even in rural areas. These studies have focused mainly on types of habitats, and on types of human disturbances, but the effect of successional stages in the same habitat has been poorly addressed in the Atlantic Forest. This is an important knowledge gap because secondary forests and/or small fragments currently correspond to $32-40 \%$ of what is left from the Atlantic Forest (Ribeiro et al. 2009).

In this study we aimed to compare the availability and characteristics of tree cavities between primary and mid-successional stage sites in an Atlantic Forest area from southeastern Brazil, and based on nest characteristics described in the literature, we inferred if hollows present in secondary sites could harbor the large secondary-nester Atlantic
Forest birds, with special attention to toucans and hawks. Specifically, we addressed the following questions: i) Does cavity availability differ between mid-successional stage and primary Atlantic Forest sites? ii) Does the amount of dead trees differ between these areas? iii) Do cavity measurements differ between these successional stages? iv) Could cavities in the mid-successional stage sites harbor the entire guild of cavity-nesting Atlantic Forest birds?

\section{Materials and Methods}

\section{Study area}

This study was conducted in Carlos Botelho State Park - PECB (2406' 55" - 24 $4^{\circ} 14^{\prime} 41^{\prime \prime} \mathrm{S}$ and $\left.47^{\circ} 47^{\prime} 18^{\prime \prime}-48^{\circ} 07^{\prime} 17^{\prime \prime} \mathrm{W}\right)$, state of São Paulo, Brazil. The park holds 37.644 ha, mainly of primary forests, and together with a number of contiguous conservation units it composes one of the largest remaining patches of Atlantic Forest, which totals more than 1.1 million ha. Altitudes are from 20 to 1,000 $\mathrm{m}$ a.s.1.; average temperatures from $18-20^{\circ} \mathrm{C}$, and mean annual precipitation is $1,676 \mathrm{~mm}$ (777-2,264 mm) (Beisiegel \& Mantovani 2006). This is one of the few Atlantic Forest parks that still preserves the original faunal assemblage, including jaguars, cougars, ocelots, and tapirs (Brocardo et al. 2012), and Antunes et al. (2013) have recorded 331 bird species in PECB, of which 52 $(15.7 \%)$ are cavity nesters. Although the PECB is mostly covered by mature forests, $33.3 \%$ of the area is represented by recovery-zones in different successional stages. Our survey was conducted in the upper part of the park, in the municipality of São Miguel Arcanjo (714-837 m in altitude), where the natural vegetation is classified as submontane Atlantic Forest. Our sampling sites were accessed by using the called "service road", a 28 $\mathrm{km}$ path that connects the main administrative base of the park to center of the conservation unit, in which only the use by researchers and park staff is permitted (see Oliveira Jr. et al. 2011). Primary forest areas were reached by choosing random points in the service road, and secondary habitats were investigated in a clearly distinguishable recovery area called "aceiro". The later is located in one of the limits of the park and has approximately 136 ha, being bisected by an approximately $3 \mathrm{~km}$ secondary trail. This area was deforested mainly for charcoal production and it has been in regeneration since 1982, when PECB was created. Currently it can be generally classified in mid-successional stage (see methods bellow).

\section{Successional stage classifications and data analyses}

Cavities were sampled in primary and mid-successional stage areas by establishing five 0.5 ha plots in each type of habitat. To determine plot locations, we first assorted numbers from the first $7000 \mathrm{~m}$ of the service road, and from the $3000 \mathrm{~m}$ of the aceiro sub-trail to generate reference sites. In these sites, we assorted the side of the road or trail and entered the forest until reaching areas that appeared to have the desirable characteristics. Then, in each of these sites we created one 0.5 ha plot, subdivided in $25 \mathrm{~m}$ wide stripes, demarked with strings.

To confirm the successional stage, we established three $10 \times 10 \mathrm{~m}$ sub-plots, one in each corner, and one in the middle of each plot, arranged diagonally. In these sub-plots we obtained diameters at breast high and height of woody trees with DBHs above $5 \mathrm{~cm}$ (Carvalho et al. 2015). Mid-successional stage was considered when DBHs of trees averaged across the three subplots were between 10 and $20 \mathrm{~cm}$, and heights between 4 - 12 m (Resolução Conjunta SMA Ibama/SP 1994, hereafter Ibama 1994). Primary, or advanced-successional stage was considered when average DBHs and heights were above $20 \mathrm{~cm}$ and $10 \mathrm{~m}$, respectively, and when woody vines, adult individuals of the palm Euterpe edulis Mart., and of the samambaiaçu Cyathea spp. were present (Ibama 1994, Lima et al. 2011). 
In each plot, we quantified the number of natural cavities, the number of woodpecker's holes, and the numbers of dead trees or branches. The minimum diameter considered for the counting of dead trees or branches was $5 \mathrm{~cm}$. We have defined a cavity as a depression in a woody tree (living or dead), which had a plateau to support an oologic chamber and had a closed cover. Cavities that were up to $7 \mathrm{~m}$ high were accessed using ladder for biometric analyses (Rendell \& Robertson 1989, Kerpz \& Smith 1990, Aitken \& Martin 2004, Martin et al. 2004). Measurements included: tree diameter at cavity height, smaller entrance diameter, internal diameter, and depth (Marini et al. 2002, Remm et al. 2006, Tamungang et al. 2016). When a cavity presented more than one entrance, we considered the measurements of the larger one as this is the one that would permit easier access by predators. As in many cavities entrance is not round shaped, but irregular, we chose measuring the smaller entrance diameter as this is what may restrict animal entrance. Height above ground was also estimated for all of the cavities.

The mean numbers of cavities (natural plus woodpecker's holes), the mean numbers of woodpecker's cavities, and of decaying trees or branches were compared between habitats using univariate $t$-tests with $\log _{10}$ data correction. The same procedure was used to compare cavities height above ground, but pooling together the data of all of the plots from each habitat. The proportion of natural versus woodpecker holes between habitats was compared through $G$-test. To compare cavity measurements between habitats, we first preformed a Principal Component Analysis (PCA) to reduce the number of variables and to seek for potential graphical clusterings that could be correlated to each type of habitat. Data was transformed using $z$-score (Gotelli \& Ellison 2011) and we used variance-covariance matrix. Then, the new scores provided for the main axis were compared between habitats by $t$-test. All of the analyses were performed using the software Past3 (Hammer et al. 2001), with 95\% significance level.

Based on the birds survey of Carlos Botelho State Park (Antunes et al. 2013), we listed all of the forest secondary cavity-nester species. Then, biometric data of their nests were consulted in literature in order to investigate if cavities with minimum dimension requirements were available in the analyzed plots. Only species that presented at least two nests described, measures of cavity smaller entrance diameter, and depth, with values range (maximum and minimum) were selected. A graphical comparison was made between the values of the smaller entrance opening and cavities depth, which proved to be the most important characteristics selected by birds in several studies (Wesolowski 2002, Cockle et al. 2008, Cockle \& Bodrati 2009).

\section{Results}

From September 2016 to April 2017, we found a total of 96 cavities, being 67 in the primary, and 29 in the secondary plots. The number of cavities per plot varied from five to 21 in the primary $(13.4 \pm 6.34)$, and from one to $13(5.8 \pm 5.07)$ in the secondary habitats, being the average number of cavities significantly higher in the primary forest $(t=2.05$, $P=0.036)$. On the other hand, the number of decaying trees or branches was significantly higher in the secondary habitats $(t=-2.92, P=0.0096)$, being 90 in the primary ( 11 to $30 ; 18.0 \pm 7.17)$, and 156 in the secondary habitats ( 21 to $42 ; 31.2 \pm 7.66$ ) (Fig. 1). Of the 67 cavities found in the primary plots, $61(91 \%)$ were in live trees or branches, and six $(9 \%)$ were in decaying structures, of which five $(7.5 \%)$ were typical woodpecker's excavations. Of the 29 cavities found in the secondary plots, $22(76 \%)$ were in live trees or braches, and seven (24\%) were in decaying structures, of which six $(20.6 \%)$ were woodpecker's excavations. Neither the proportion of natural versus woodpecker holes $(G=3.21, P=0.07)$, nor the average numbers of woodpeckers cavities $(t=0.11, P=0.45)$ have different between habitats (Figure 1), and $100 \%$ of the holes excavated by woodpeckers occurred in decaying substrate.

Cavities average heights above ground were $8.17 \pm 7.96$ (0.34 - 25; $n=67)$ in the primary, and $3.52 \pm 2.48(0.56-10 ; n=26)$ in the secondary plots, being significantly different $(t=2.08, P=0.02)$. Of the 96 cavities, 51 were accessible but one was not measured because of the presence of bees in primary forest, and three were not considered because they were full of water, all of them in secondary forest, indicating that they were inadequate for birds reproduction. Then, measurements were obtained for 47 cavities, being 32 in the primary plots and 15 in the secondary habitats (Table 1). In the PCA, 95.4\% of the variation was explained by the first two axes, with the first axis concentrating $78.72 \%$ of the variation. There was no graphical evidence for clustering (Figure 2), and the $t$-test performed to compare the new scores of the main axis (component 1 ) was not significant $(t=0.0, P=0.50)$, indicating that cavities presented similar characteristics in the two types of habitats.

Of the 62 cavity-nester bird species recorded for PECB, only nine had nest measurements available in the literature that attended our selection criteria for depth (Figure 3), and seven for entrance diameter (Figure 4) comparisons. These graphical comparisons permitted to observe that cavities from both habitats provided minimal depth requirements for nesting of all of the analyzed species, but in the mid-successional stage areas the cavities we found might exclude the large Collared Forest Falcon, Micrastur semitorquatus (approximately $50 \mathrm{~cm}$ ) based on entrance diameters.

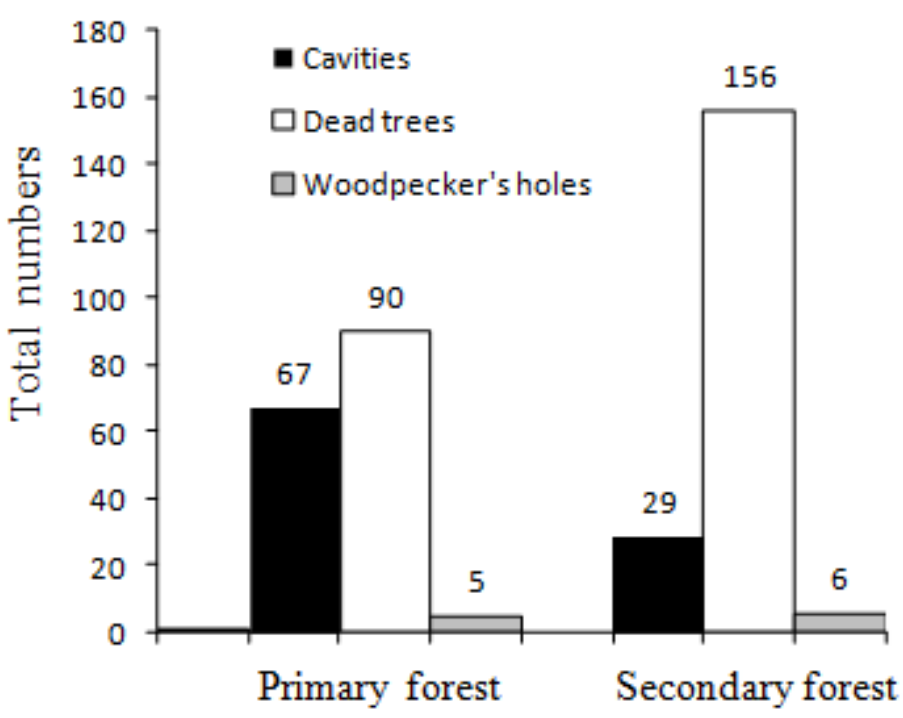

Figure 1. Numbers of cavities (natural cavities plus woodpecker's roles), numbers of dead trees or branches, and numbers of woodpecker's holes found pooled across five 0.5 ha plots in primary and mid-successional stage Atlantic Forest areas.

Table 1 - Average and standard deviation values for cavities measures in different successional stages.

\begin{tabular}{|c|c|c|c|c|c|}
\hline Successional stage & $\begin{array}{c}\text { Smaller entrance } \\
\text { diameter }\end{array}$ & Internal diameter & Height above ground & DBH at nest height & Cavity depth \\
\hline Primary & $6.63 \pm 3.9$ & $12.93 \pm 6.91$ & $182.29 \pm 118.51$ & $36.02 \pm 18.92$ & $36.14 \pm 40.98$ \\
\hline Mid-successional & $4.79 \pm 2.32$ & $10.94 \pm 5.20$ & $194.15 \pm 101.45$ & $23.76 \pm 7.29$ & $13.29 \pm 34.21$ \\
\hline
\end{tabular}




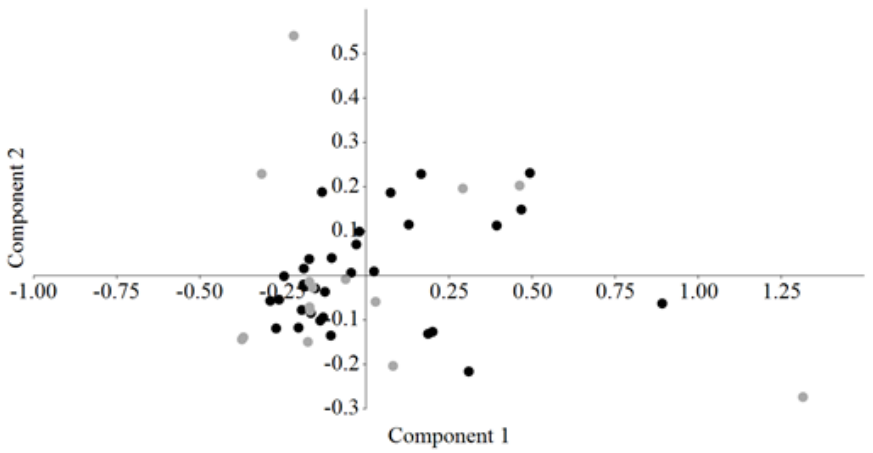

Figure 2. Principal Component Analysis (PCA) evidencing the distribution of cavities based on their measurements (tree diameter at cavity height, smaller entrance diameter, internal diameter, and depth). The new scores distributed between the two main axes did not reveal any clustering tendency between primary (black dots), and mid-successional stage (gray dots) Atlantic Forest areas.

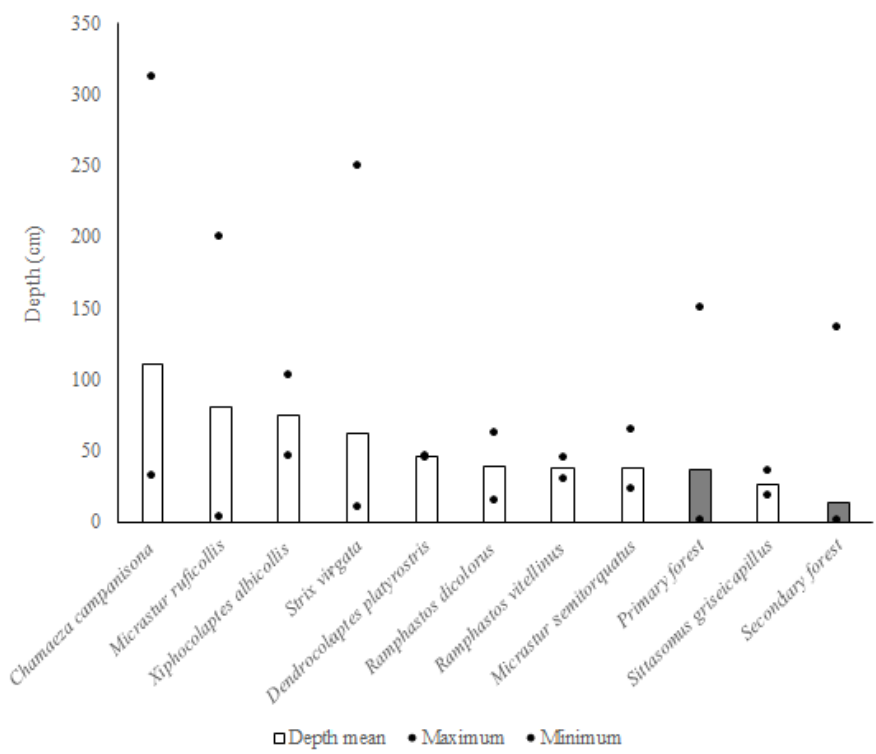

Figure 3. Comparisons of cavity nests depth found for bird species occurring in $\mathrm{PECB}$, and depths found for cavities available in primary and mid-successional stage Atlantic Forest areas (Lange 1967, Lill 1968, Thorstrom et al. 1990, 2000, Thorstrom 2001, Gerhardt 2004, Cockle \& Bodrati 2009, Jesus \& Mikish 2009, Bodrati et al. 2012, Jesus et al. 2012, Cockle \& Bodrati 2013, Holt et al. 2016).

\section{Discussion}

Our main prediction of reduced number of cavities in mid-successional stage areas was corroborated and our data suggested that only advanced successional stage, or primary areas, may present the density of cavities expected for natural Atlantic Forest habitats. Notably, the Brazilian legislation (Ibama 1994) do not make any distinction between advanced successional stage and primary Atlantic Forests, then both must be representative of the original conditions. To our knowledge, this is the first work to provide evidences for such successional effect in a Neotropical humid forest, and it is consistent with studies carried out in Europe and Thailand where the number of cavities was higher in older conifer forests and mixed deciduous forest, respectively (Van Balen et al. 1982, Pattanavibool \& Edge 1996). Hypotheses that attempt to explain the greater number of cavities in mature

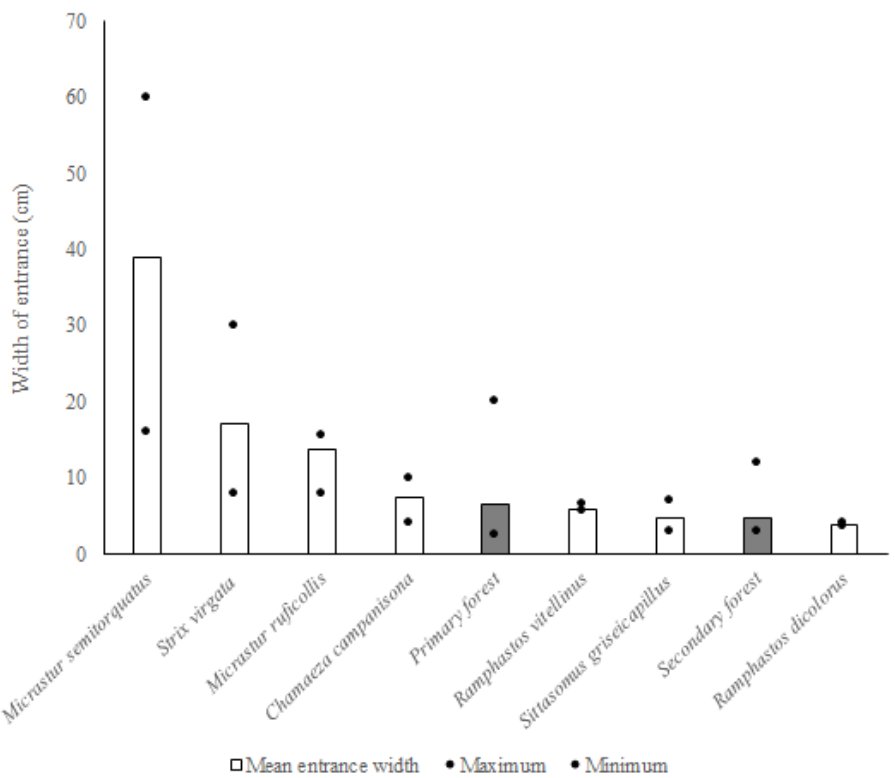

Figure 4. Comparisons of the smaller entrance diameters of cavities used by bird species occurring in PECB, and diameters found for cavities available in primary and mid-successional stage Atlantic Forest areas (Lange 1967, Lill 1968, Thorstrom et al. 1990, 2000, Thorstrom 2001, Gerhardt 2004, Cockle \& Bodrati 2009, Jesus \& Mikish 2009, Bodrati et al. 2012, 2014, Jesus et al. 2012, Cockle \& Bodrati 2013, Holt et al. 2016).

forests involve the greater biodiversity, greater structural complexity, and higher forest productivity (Cornelius et al. 2008).

The greater number of dead trees and branches in secondary sites was also consistent with other studies, not only from the Atlantic Forests (Aleixo 1999, Carvalho et al. 2007), but also from temperate forests (Kirby et al. 1998). According to Ibama (1994) and Carvalho et al. (2015), in mid-succesional regeneration stage the fast growing pioneer trees die as they get replaced by primary species during the ecological succession process, which may explain the greater amount of dead trees in this type of secondary formation (Kirby et al. 1998, Carvalho et al. 2015). Further, the decomposition of dead substrate must be faster in primary areas due to increased humidity and diversity of decomposers, which reduces the number of decaying structures (Cornelius et al. 2008). As woodpecker's nests were always constructed in decaying substrate, the lack of difference in the proportion of natural versus woodpecker's nests between successional stages was unexpected, and may be explained by the low representativeness of woodpecker's cavities in general. In North America, for instance, woodpeckers were responsible for constructing $77 \%$ of the available cavities (for a review, see Cockle et al. 2011b), which is much more than the $28.1 \%$ (pooled between habitats) observed here. Then, the differences in cavities availability between habitats observed here involved mostly the numbers of natural holes in live trees, and they may be more common in the largest and older trees found in primary forests.

Although cavity characteristics have not diverged significantly between habitats, our graphical comparisons revealed that hollows in primary habitats exhibited the minimal depth and entrance diameter requirements for birds nesting, including the largest cavity-nester species present in the PECB, such as hawks, toucans and owls. In the mid-succesional stage sites, on the other hand, entrance diameter seemed to be a restrictive characteristic for the largest cavity nester birds.

It is important to note that, although most of the bird species considered in our comparisons could theoretically nest in cavities from both successional stages, here we have not considered other important parameters that are 
often involved in nesting habitat and nesting site choice by birds, for instance, canopy closure, and vegetation density (Cockle et al. 2015). Then, based on cavities characteristics alone our analyses certainly tend to overestimate the usefulness of the cavities.

In general, our data revealed that in the recovery area we studied, the communities of cavity-nester birds may be more affected by the reduced cavity availability than by cavities quality, as the number of cavities in mid-succesional stage sites was less than half than that found in mature forests. We also provide evidences that the largest cavity nesters, such as the biggest hawks, might have limited nesting possibilities in mid-seccessional stage areas. Management strategies currently used to overcome these problems involve the distribution of nest boxes and the enlargement of the entrances of part of the available cavities (Kuniy et al. 2006, Smallwood et al. 2009, Olah et al. 2014). In face of the evidences provided here, we suggest that these strategies might be considered for the preservation of the guild of Atlantic Forest cavity-nester birds in areas classified in mid- or lower successional stages.

\section{Acknowledgments}

We thank ICMBIO and Fundação Florestal for their permissions for field work in PECB (SISBIO n ${ }^{\circ}$ 54239-1 and COTEC n ${ }^{\circ} 260108$ - 005.706 / 2016); Brazilian agencies Coordenação de Aperfeiçoamento de Pessoal de Nível Superior (CAPES) and Conselho Nacional de Desenvolvimento Científico e Tecnológico (CNPq) for financial support. We are also grateful to field guides Hiago Ermenegildo and Édipo Fernandes, and the volunteers Bárbara Cirillo, Bárbara Cantoni, Cristiane Santos, and Leandro Vitor for field assistance.

\section{Author contributions}

Michele Viana Katayama: substantial contribution in the concept and design of the study; contribution to data collection; contribution to data analysis and interpretation; contribution to manuscript preparation; contribution to critical revision, adding intelectual content.

Paulo Victor Queijo Zima: substantial contribution in the concept and design of the study; contribution to data collection; contribution to data analysis and interpretation; contribution to critical revision, adding intelectual content.

Daniel Fernandes Perrella: substantial contribution in the concept and design of the study; contribution to data collection; contribution to data analysis and interpretation; contribution to critical revision, adding intelectual content.

Mercival Roberto Francisco: substantial contribution in the concept and design of the study; contribution to data analysis and interpretation; contribution to manuscript preparation; contribution to critical revision, adding intelectual content.

\section{Conflicts of interest}

The authors declare that they have no conflict of interest related to the publication of this manuscript.

\section{References}

AITKEN, K., WIEBE, K.L. \& MARTIM, K. 2002. Nest-site reuse patterns for a cavity-nesting bird community in interior British Columbia. Auk 119:391-402.

AITKEN, K.E.H. \& MARTIN, K. 2004. Nest cavity availability and selection in Aspen-conifer groves in a grassland landscape. Can. J. For. Res. 34:2099-2109.

ALEIXO, A. 1999. Effects of selective logging on a bird community in the Brazilian Atlantic Forest. Condor 101:537-548.
ANTUNES, A.Z., SILVA, B.G., MATSUKAMA, C.K., ESTON, M.R. \& SANTOS, A.M.R. 2013. Aves do Parque Estadual Carlos Botelho. Biota Neotrop. 13:124-140.

BAI, M.L., WICHMANN, F. \& MÜHLENBERG, M. 2003. The abundance of tree holes and their utilization by hole-nesting birds in a primeval boreal forest of Mongolia. Acta Ornithol. 38:95-102.

BEISIEGEL, B.M. \& MANTOVANI, W. 2006. Habitat use, home range and foraging preferences of Nasua nasua in a pluvial tropical Atlantic Forest area. J. Zool. 269:77-87.

BODRATI, A., COCKLE, K.L., SALVADOR, S.A. \& KLAVINS, J. 2012. Nesting of the olivaceous woodcreeper (Sittasomus griseicapillus). Ornitol. Neotrop. 23:325-334.

BODRATI, A., COCKLE, K.L. \& DI SALLO, F.G. 2014. Nesting of the shorttailed antthrush (Chamaeza campanisona) in the Atlantic Forest of Argentina. Ornitol. Neotrop. 25:421-431.

BROCARDO, C.R., RODARTE, R., BUENO, R.S., CULOT, L. \& GALETTI, M. 2012. Mamíferos não voadores do Parque Estadual Carlos Botelho, Continuum florestal do Paranapiacaba. Biota Neotrop. 12:198-208.

CARVALHO, F.A., BRAGA, J.M.A. \& NASCIMENTO, M.T. 2015. Tree structure and diversity of lowland Atlantic forest fragments: comparison of disturbed and undisturbed remnants. J. For. Res. 27:605-609.

CARVALHO, F.A., NASCIMENTO, M.T. \& BRAGA, J.M.A. 2007. Estrutura e composição florística do estrato arbóreo de um remanescente de Mata Atlântica submontana no município de Rio Bonito, RJ, Brasil (Mata Rio Vermelho). R. Árvore 31:717-730.

COCKLE, K.L. \& BODRATI, A. 2009. Nesting of the Planalto Woodcreeper (Dendrocolaptes platyrostris). Wilson J. Ornithol. 121:789-795.

COCKLE, K.L. \& BODRATI, A. 2013. Nesting of the White-throated Woodcreeper Xiphocolaptes albicollis. 2013. Wilson J. Ornithol. 125:782-789.

COCKLE, K.L., BODRATI, A., LAMMERTINK, M. \& MARTIN, K. 2015. Cavity characteristics, but not habitat, influence nest survival of cavity-nesting birds along a gradient of human impact in the subtropical Atlantic Forest. Biol. Conserv. 184:193-200.

COCKLE, K.L., MARTIN, K. \& DREVER, M.C. 2010. Supply of tree-holes limits nest density of cavity-nesting birds in primary and logged subtropical Atlantic Forest. Biol. Conserv. 143:2851-2857.

COCKLE, K.L., MARTIN, K. \& WIEBE, K. 2008. Availability of cavities for nesting birds in the Atlantic Forest, Argentina. Ornitol. Neotrop. 19:269-278.

COCKLE, K.L., MARTIN, K. \& WIEBE, K. 2011a. Selection of nest trees by cavity-nesting birds in the Neotropical Atlantic Forest. Biotropica 43:228-236.

COCKLE, K.L., MARTIN, K. \& WESOLOWSKI, T. 2011b. Woodpeckers, decay, and the future of cavity-nesting vertebrate communities worldwide. Front. Ecol. Environ. 9:377-382.

CORNELIUS, C., COCKLE, K.L., POLITI, N., BERKUNSKY, I., SANDOVAL, L., OJEDA, V., RIVERA, L., HUNTER JR., M. \& MARTIN, K. 2008. Cavitynesting birds in neotropical forests: cavities as a potentially limiting resource. Ornitol. Neotrop. 19:253-268.

DOBKIN, D.S., RICH, A.C., PRETARE, J.A. \& PYLE, W.H. 1995. Nest-site relationship among cavity-nesting birds of riparian and snowpocket aspen woodlands in the northwestern Great Basin. Condor 97:694-707.

FRANCO, A.M., MARQUES, J.T. \& SUTHERLAND, W.J. 2005. Is nest-site availability limiting Lesser Kestrel populations? A multiple scale approach. Ibis 147:657-666.

GERHARDT, R.P. 2004. Cavity nesting in raptors of Tikal National Park and vicinity, Petén, Guatemala. Ornitol. Neotrop. 15:477-483.

GOTELLI, N.J. \& ELLISON, A.M. 2011. Princípios de estatística em ecologia. Porto Alegre. Artmed, Brazil.

HAMMER, O., HARPER, D.A.T. \& RYAN, P.D. 2001. Past: Palaeonthological statistics software package for education and data analysis. Version. 1.37. Available from http://palaeoelectronica.org/2001_1/past/issue1_01.htm (accessed 22.04.2017).

HOLT, D.W., BERKLEY, R., DEPPE, C., ENRÍQUEZ R.P., PETERSEN, J.L., RANGEL SALAZAR, J.L., SEGARS, K.P., WOOD, K.L. \& KIRWAN, G.M. 2016. Mottled Owl (Ciccaba virgata). In: del Hoyo, J., Elliott, A., Sargatal, J., Christie, D.A. \& de Juana, E. (eds.). Handbook of the Birds of the World 
Alive. Lynx Edicions, Barcelona. Available in: http://www.hbw.com/node/55046 (accessed in 09.12.2016).

IBAMA. 1994. BRASIL. RESOLUÇÃO CONJUNTA SMA IBAMA/SP nº 1 , de fevereiro de 1994.

JACKSON, J.A. \& JACKSON, B.J.S. 2004. Ecological relationships between fungi and woodpecker cavity sites. Condor 106:37-49.

JESUS, S. \& MIKICH, S.B. 2009. Registro de nidificação de Dendrocolaptes platyrostris (Dendrocolaptidae) em forro de edificação semi rural. Rev. Bras. Ornitol. 17:79-81.

JESUS, S., BUZZATO, A.C. \& MONTEIRO-FILHO, E.L.A. 2012. Nidificação de Ramphastos dicolorus (Linnaeus, 1766) (AVES: Ramphastidae) na região metropolitana de Curitiba, Estado do Paraná. Ornithologia 5:19-25.

KERPEZ, T.A. \& SMITH, N.S. 1990. Nest-site selection and nest-cavity characteristics of Gila Woodpeckers and Northern Flickers. Condor 92:193-198.

KIRBY, K.J., REID, C.M., THOMAS, R.C. \& GOLDSMITH, F.B. 1998. Preliminary estimates of fallen dead wood and standing dead trees in managed and unmanaged forests in Britain. J. Appl. Ecol. 35:148-155.

KUNIY, A.A., FIGUEIREDO, I.C.S. \& GUEDES, N.M.R. 2006. Handling technique to increase the Hyacinth Macaw population (Anodorhynchus hyacinthinus) (LALHAM, 1720) - report of an experience in Pantanal, Brazil. Braz. J. Biol. 66:381-382.

LANGE, R.B. 1967. Ramphastos dicolorus L. (Ramphastidae), sua nidificação e ovos. Zoologia 1: $1-3$.

LI, P. \& MARTIN, T.E. 1991. Nest-site selection and nesting success of cavitynesting birds in high elevation forest drainages. Auk 108:405-418.

LILL, A. 1968. Nidification in the Channel-billed Toucan (Ramphastos vitellinus) in Trinidad, West Indies. Condor 72:235-236.

LIMA, R.A.F., DITTRICH, V.A.O., SOUZA, V.C., SALINO, A., BREIER, T.B. \& AGUIAR, O.T. 2011. Vascular flora of the Carlos Botelho State Park, São Paulo, Brazil. Biota Neotrop. 11(4):173-214.

LÕHMUS, A. \& REMM, J. 2004. Nest quality limits the number of hole-nesting passerines in their natural cavity-rich habitat. Acta Oecol. 27:125-128.

MARINI, M.A., LOPES, L.E., FERNANDES, A.M. \& SEBAIO, F. 2002. Descrição de um ninho de Lepidocolaptes fuscus (Dendrocolaptidae) no nordeste de Minas Gerais, com dados sobre sua dieta e pterilose dos ninhegos. Ararajuba 10:95-98.

MARTIN, K., AITKEN, K.E.H. \& WIEBE, K.L. 2004. Nest sites and nest webs for cavity-nesting communities in interior British Columbia, Canada: nest characteristics and niche partitioning. Condor 106:5-19.

MARTIN, K. \& EADIE J.M. 1999. Nest webs: A community-wide approach to the management and conservation of cavity-nesting forest birds. For. Ecol. Manage. 115:243-257.

MILLER, K.E. 2002. Nesting success of the great crested flycatcher in nest boxes and in tree cavities: are nest boxes safer from nest predation? Wilson Bull. 114:179-185.

MYERS, N., MITTERMEIER, R.A., MITTERMEIER, C.G., FONSECA, G.A.B. \& KENT, J. 2000. Biodiversity hotspots for conservation priorities. Nature 403:853-845.

OLAH, G., VIGO, G., HEINSOHN, R. \& BRIGHSMITH, D.J. 2014. Nest site selection and efficacy of artificial nests for breeding success of Scarlet Macaws Ara macao macao in lowland Peru. Nature Conserv. 22:176-185.

OLIVEIRA JR, P.R.R., ALBERTS, C.C. \& FRANCISCO, M.R. 2011. Impact of road clearings on the movements of three understory insectivorous bird species in the Brazilian Atlantic Forest. Biotropica 43:628-632.

PATTANAVIBOOL, A. \& EDGE, W.D. 1996. Single-tree selection silviculture affects cavity resources in mixed deciduous forest in Thailand. J. Wildl. Manage. 60:67-73.

PIACENTINI, V.Q., ALEIXO, A., AGNE, C.E., MAURÍCIO, G.N., PACHECO, J.F., BRAVO, G.A., BRITO, G.R.R., NAKA, L.N., OLMOS, F., POSSO, S., SILVEIRA, L.F., BETINI, G.S., CARRANO, E., FRANZ, I., LEES, A.C.,
LIMA, L.M., PIOLI, D., SCHUNCK, F., AMARAL, F.R. BENCKE, G.A., COHN-HAFT, M., FIGUEIREDO, L.F.A., STRAUBE, F.C. \& CESARI, E. 2015. Annotated checklist of the birds of Brazil by the Brazilian Ornithological Records Committee/Lista comentada das aves do Brasil pelo Comitê Brasileiro de Registros Ornitológicos. Rev. Bras. Ornitol. 23:91-298.

POLITI, N., HUNTER J.R.M. \& RIVERA, L. 2010. Availability of cavities for avian cavity nesters in selectively logged subtropical montane forests of the Andes. Forest. Ecol. Manag. 260:893-906.

REMM, J., LÕHMUS, A. \& REMM, K. 2006. Tree cavities in riverine forests What determined the occurrence and use by hole-nesting passarines? Forest. Ecol. Manag. 221:267-277.

REMSEN JR, J.V., ARETA J.I., CADENA, C.D., JARAMILLO, A., NORES, M., PACHECO, J.F., PÉREZ-EMÁN, J., ROBBINS, M.B., STILES, F.G., STOTZ, D.F. \& ZIMMER K.J. 2015. A classification of the bird species of South America. American Ornithologists' Union. Available in: http://www.museum. 1su.edu/ Remsen/SACCBaseline.html (accessed in 10.05.2017).

RENDELL, W.B. \& ROBERTSON, R.J. 1989. Nest-site characteristics, reproductive success and cavity availability for tree swallows breeding in natural cavities. Condor 91:875-885.

RIBEIRO, M.C., METZGER, J.P., MARTENSEN, A.C., PONZONI, F.J. \& HIROTA, M.M. 2009. The Brazilian Atlantic Forest: How much is left, and how is the remaining forest distributed? Implications for conservation. Biol. Conserv. 142:1141-1153.

SMALLWOOD, J.A., CAUSEY, M.F., MOSSOP, D.H, KLUCSARITS, J.R., ROBERTSON, B., ROBERTSON, S., MASON, J., MAURER, M.J., MELVIN, R.J., RUSSELL, D.D., BORTOLOTTI, G.R., PARRISH JR., J.W.M., BREEN, T.F. \& BOYD, K. 2009. Why are American kestrel (Falco sparverius) populations declining in North America? Evidence from nest-box programs. J. Raptor Res. 43:214-282.

SOS MATA ATLÂNTICA, Instituto Nacional de Pesquisas Espaciais. 2016. Atlas dos remanescentes florestais e ecossistemas associados no domínio da Mata Atlântica. São Paulo. Available in: https://www.sosma.org.br/projeto/atlas-damata-atlantica/ (accessed in 23.05.2017).

TAMUNGANG, S.A., KOUGOUM, G.P.N. \& TEGUIA, A. 2016. Nest characteristics for the conservation of the Grey Parrot in Cameroon. J. Ecol. Nat. Environ. 8:142-154.

THORSTROM, R. 2001. Nest-site characteristics and breeding density of two sympatric forest-falcons in Guatemala. Ornitol. Neotrop.12:337-343.

THORSTROM, R.K., RAMOS, J.D. \& CASTILLO, J.M. 2000. Breeding biology and behavior of the Collared Forest-Falcon (Micrastur semitorquatus) in Guatemala. Ornitol. Neotrop. 11:1-12.

THORSTROM, R.K., TURLEY, C.W., RAMIREZ, F.G. \& GILROY, B.A. 1990 Description of nests, eggs and young of the Barred Forest-Falcon (Micrastur ruficollis) and of the Collared Forest-Falcon (M. semitorquatus). Condor 92:237-239

VAN BALEN, J.H., BOOY, C.J.H., VAN FRANEKER, J.A. \& OSIECK, E.R. 1982 Studies on hole nesting birds in natural nest sites. Ardea 70:1-24

WESOLOWSKI, T. 2002. Anti-predator adaptations in nesting Marsh Tits Parus palustris: the role of nest-site security. Ibis 144:593-601.

WIEBE, K.L. \& SWIFT, T.L. 2001. Clutch size relative to tree cavity size in Northern Flickers. J. Avian Biol. 32:167-173.

WILLIS, E.O. \& ONIKI, Y. 2001. On a nest of the Planalto Woodcreeper, Dendrocolaptes platyrostris, with taxonomic and conservation notes.Wilson Bull. 113:231-233. 